\title{
Quality Assurance or Election Fodder? - The Politics of Teacher Testing in Ontario, $1999-2003$
}

\author{
Larry A. Glassford
}

\begin{abstract}
A commitment to mandatory teacher testing formed part of the victorious Conservative government's platform in the Ontario provincial election of 1999. For the next four years it sought to implement the controversial policy, over the objections of the organized teacher federations. Caught in the middle was the fledgling Ontario College of Teachers, which was used by the government to implement a policy opposed by its own membership. The two most contentious aspects of the teacher-testing program were a qualifying test for prospective new teachers, and mandatory recertification for veteran instructors. After four years, the program was only partially in place. Working behind the scenes, the teachers helped to defeat the government at the next general election. Whatever the motivation for the initial policy - public accountability or crass electioneering - a confrontational implementation led to its ultimate demise.
\end{abstract}

\section{RÉSUMÉ}

L'engagement de rendre obligatoire l'évaluation des maîtres fit partie de la campagne du gouvernement conservateur lors des élections provinciales ontariennes de 1999. Durant les quatre années suivantes, ce gouvernement chercha à mettre en pratique cette politique controversée en dépit des objections des fédérations syndicales enseignantes. L'Ontario College of Teachers, une association inexpérimentée, s'est retrouvée coincée entre le gouvernement qui voulait l'utiliser pour implanter cette mesure et ses propres membres qui, eux, şy objectaient. Le test de vérification des compétences des nouveaux maîtres et la recertification obligatoire des éducateurs d'expérience furent les aspects les plus controversés du programme d'évaluation des maitres. En 2003, seule une partie du programme était effective. Oeuvrant en coulisses, les maittres contribuèrent à défaire le gouvernement lors des élections provinciales suivantes. Quels que furent les objectifs de la politique initiale - responsabilité publique ou grossière propagande électorale - sa mise en application conflictuelle conduisit à sa disparition. 


\section{Prologue}

The concept of "teacher testing" as serious public policy first entered Ontario's political arena in the spring of 1999 when the Office of the Premier, Mike Harris, issued a "Blueprint for Ontario" on April 19, just prior to an expected provincial election. "We'll require all Ontario teachers to participate in a testing program to stay up to date," the press release declared. "We will require all teachers to take and pass re-certification examinations every three to five years."

Harris and the Progressive Conservative party went on to win re-election in the subsequent June election, and shortly thereafter, the new Minister of Education, Janet Ecker, began the process of implementation. The policy was controversial from the start. It pitted party against party, teacher federations against the Ministry of Education and public interest group against public interest group. Caught in the middle was the fledgling Ontario College of Teachers, which was assigned a major role in both the advisory and implementation phases.

After four years had passed, the teacher-testing policy was still hotly controversial and only partially in place. In the provincial election campaign of 2003, both Opposition parties pledged to end the Conservative government's teacher re-certification program, while the Conservative government, now led by Ernie Eves, stoutly defended it. On election day in October, the Liberals led by Dalton McGuinty swept to a decisive majority. In their ensuing Throne Speech of November 20, they included a pledge to "replace the expensive and unproductive 'teacher testing' program." ${ }^{2}$ The policy was dead. Or was it? And why had it appeared, seemingly out of the blue, in the first place? What combination of forces had first nurtured then killed it?

\section{Political Context}

The bulk of attention, scholarly as well as journalistic, that has been devoted to the Harris government has focused on its first term of office. ${ }^{3}$ Astutely packaged as the "Common Sense Revolution," the Progressive Conservative (PC) Party's initial program was a beguiling blend of neo-liberalism, populism and traditional conservatism. After a dramatic victory in the 1995 provincial election, the Harris PCs had turned Ontario politics on its head by proceeding with relentless determination to implement the vision upon which they had campaigned. In the field of education, this quickly led them into open confrontation with the powerful teacher federations, who had contributed to the defeat of the previous New Democratic Party (NDP) government led by Bob Rae. It was not that the teachers had campaigned for the PCs in 1995, but rather that they had refused to support a traditional ally, the NDP. This stance was in strong contrast to the 1990 campaign, when they had worked energetically to help bring down a Liberal government headed by David Peterson. Two years of increasingly bitter confrontation between the new PC government and the teacher "unions" (as they increasingly thought of themselves), culminated in a dramatic, two-week provincewide teacher walkout, which closed every publicly-funded elementary and secondary school in the province, in the fall of 1997 . Ultimately, the Harris PCs stared the teachers down, and Bill 160, the legislation by which they centralized the control of school 
policy and finance even more securely in the provincial government's hands, was passed into law over the objections of the teacher unions. ${ }^{4}$ It would prove to be a pyrrhic victory for the Harris Conservatives, however, and though they rallied public opinion in their favour long enough to win a second term of office in 1999, the long-term swing in public opinion that began during the 1997 teacher walkout, continued to work against them. This trend was not evident in mid-1999, though, for the PCs stood triumphantly re-elected, while the teacher federations privately licked their wounds and vowed revenge.

In Ontario's parliamentary system, the PC government constantly faced the ritualistic criticism expected from the two Oppositions parties: the Liberals and the NDP. The news media, both traditional print and newer electronic versions, provided some scrutiny in their historic 'fifth estate' roles. The most sustained opposition faced by the Harris PCs proved to be extra-parliamentary, however, and centred upon the province's trade unions. While they could and did intervene during the 1999 election campaign, these organized interest groups developed political-action strategies that sought to bring pressure to bear on most aspects of Ontario's political system: ${ }^{5}$ shaping public opinion, lobbying MPPs, providing evidence before legislative committees, challenging statutes and regulations before the courts, and from time to time, defying the laws through civil disobedience. During the Harris years, no interest group was more active in utilizing democratic forms of political influence and protest than the organized teacher unions.

While there is some dispute as to how revolutionary the content of the Conservative educational policy was, there can be no doubt that the governing style and reforming zeal of the Harris-led government marked a sharp break with tradition. ${ }^{6}$ The party's winning election platform, dubbed the "Common Sense Revolution," had specified that the solutions to Ontario's problems, including those in its school system, were simple and straightforward. Acting upon this assumption once they were sworn to office, the PCs proceeded to devise and implement policies quickly and implement them forcefully. They did not shrink from confrontation. Indeed, at times it seemed that they welcomed it. Armed with their own electoral endorsement, they brooked no opposition. Groups and individuals who disagreed with the government's programs were branded as "special interest groups," selfishly opposed to the public will.

This steam-roller approach was in sharp contrast to the consensual governing style to which Ontarians were accustomed, and which was often associated with an earlier incarnation of Progressive Conservatives led by long-time Premiers Bill Davis and John Robarts. While sharp differences of opinion might surface from time to time, policy change was usually achieved incrementally, after much public consultation. Actual program innovations were accomplished through a broad-based partnership that included the widest possible range of affected interests. A Canadian political scientist, Paul Pross, has dubbed this overall approach the "policy community" model. ${ }^{7}$ Here is a capsule description of how it operates:

A policy community is that part of a political system that has acquired a dominant voice in determining government decisions in a field of public activity. This is by virtue of its functional responsibilities, its vested interests, and its specialized 
knowledge. The policy community is generally permitted by society at large and the public authorities in particular to create public policy in that field. It is populated by government agencies, pressure groups, media people, and individuals, including academics, who have an interest in a particular policy field and and attempt to influence it.

It was precisely this cozy, private and elitist arrangement that most offended the populist element within Harris's PCs. Armed with a popular mandate, they intended to remake Ontario, including its school system, in their own somewhat neo-conservative image. They established the priorities and dictated the policies. It was the job of the bureaucrats and special-purpose agencies to figure out how to make the new programs work. The Harris Conservatives did not seek compromise between what they saw as the failing old policies of others and their own innovative new ones. Organized teachers with a different vision for education were not seen as key stakeholders to be wooed or placated, but rather as a reactionary obstacle to progress that must be overcome. With a four-year track record of successfully imposing their will on provincial education policy, the Harris-led PCs approached teacher testing as just one more element in their topdown, yet market-driven, vision for Ontario schools.

\section{Launching the Policy}

In April 1999, the PC government led by Premier Mike Harris was approaching the fourth anniversary of its majority victory in the landmark election of 1995 . After four hectic years devoted to implementing its controversial "Common Sense Revolution," the PC government trailed the Opposition Liberals in most opinion polls, including its own internal ones. Winning re-election would not be easy. Harris had re-assembled the team of backroom strategists and campaign advisors who masterminded the upset win in 1995 . One of their key moves was to craft the pre-election manifesto entitled "Blueprint For Ontario," and sub-titled on the party website, "Mike Harris' Plan to Keep Ontario on the Right Track." Under the heading of "A Better Future," the PCs pledged the creation of a Charter of Education Rights and Responsibilities. A key element in this "charter" was the teacher-testing commitment:

We have excellent teachers in Ontario but the world is changing rapidly and we have got to make sure all teachers are keeping up. They must have the up-to-date skills, training and knowledge to put our students at the top. It's common sense to make sure that our teachers are the best-qualified and skilled professionals, so, working with the College of Teachers, we'll require all Ontario teachers to participate in a testing program to stay up to date. ${ }^{8}$

The "Blueprint" stated that teachers would be required to "take and pass re-certification examinations" every three to five years, or risk losing the right to teach. When asked what would happen to teachers who failed the re-certification test, Harris replied, "[f]or students, the last resort of remediation is summer school and maybe it should be the same for teachers." 
In fairness to the Progressive Conservative government, the election promise of ongoing teacher evaluation did fit into one of their key principles: namely, the concept of accountability to the public for the disbursement of tax dollars. Education was a big-ticket item in the provincial budget and a substantial proportion of those funds went toward teacher salaries. What guarantee did the public have that these same teachers were maintaining acceptable standards of qualification and performance over a three-to-four-decade career? For their part, the teachers pointed to the concept of professionalism, maintaining that ample evidence existed of voluntary professional development that maintained Ontario teachers at the forefront of their field. But the Harris PCs urged the adoption of a more impartial, arms-length process to determine the validity of that claim. Across the United States, various forms of teacher testing had come into vogue ${ }^{10}$ and Ontario Conservatives adopted this policy as their own. It seemed to promise both voter support, in the short run, and quality assurance in a vital profession, over the long term.

The pledge on teacher testing was only one of many promises in the PCs' pre-election platform, but it nonetheless sparked a firestorm of protest. Opposition Leader, Dalton McGuinty, denounced the plan immediately and accused the Premier of seeking to wage war on the teachers. He noted the pledge was not for a one-time province-wide testing of all new teachers, as his Liberal party was proposing, but for testing experienced teachers "on an ongoing basis, which is something we don't subject our lawyers to, our doctors to, our engineers to or our architects." Liz Sandals, president of the Ontario Public School Board Association, scoffed at the need for teacher testing. "If there is a teacher who is not performing his or her job properly," she noted, "there are already processes in place such as performance reviews that principals and boards carry out." This view was echoed by Gail Nyberg, chairwoman of the Toronto District School Board. "There is nothing wrong with the idea of evaluating teachers, we do it all the time," she declared, "but to announce it this way, without consulting the teachers, is clearly designed to pick a fight." Sure enough, that was how Liz Barkley, president of the Ontario Teachers' Federation (OTF) saw the situation. "It's insulting to say without any discussion that we all need to be recertified," she charged. Marshall Jarvis, president of the Ontario English Catholic Teachers Association (OECTA), accused the premier of spreading the impression that "teachers are not professional, that they don't keep up to date, and I have to say that's a blatant lie." Earl Manners, president of the Ontario Secondary School Teachers' Federation, suggested the PCs were using the provocative teacher-testing proposal to draw attention away from their prior failures in educational reform. ${ }^{11}$

In perhaps the oddest position after the announcement was the Ontario College of Teachers (OCT), the governing body for the teaching profession. In existence for only three years, and not yet accepted as legitimate by the teacher federations, it was being handed a controversial, complex and costly job about which it had never been consulted. "We were not aware of this plan at all," said Denys Giguere, media representative of the OCT. The day after the "Blueprint for Ontario" was released, a spokesperson for the Education Minister, Dave Johnson, confirmed that the implementation of the teacher-testing plan would be left to the College of Teachers. Once again, Giguere denied OCT awareness of the plan, stating baldly that the College was 
not ready to take on the role of ongoing teacher testing. Two days later, the chair of the College Council, Donna Marie Kennedy, reiterated that the government's teacher recertification proposal came as a complete surprise to the fledgling regulatory body. A hastily arranged visit to the Minister of Education's office, apparently clarified little. "Mr. Johnson assured us that his ministry will consult the College," said Kennedy. "However we still do not know any more about the thinking behind this proposal than we did after reading the Premier's news release." 12

After a Throne Speech, which focussed on the importance of strong leadership, and a good news Budget, Premier Harris finally called the election on May 5, with voting set for June 3. The Liberals' narrow lead in the polls evaporated during the four-week campaign, particularly after McGuinty, their first-time leader, stumbled during the televised leaders' debate. Near the end of the campaign, Harris returned to the teachertesting theme at a press conference in Oakville, Ontario. "One of our first priorities following the election," he stated, "will be to ask the College of Teachers to prepare a work plan to move ahead with implementation of teacher testing." The initial phase of the program was to start in June, 2000, with full implementation by September, 2001. The Premier linked teacher testing to the PC government's ongoing emphasis on increased accountability in the province's publicly-funded school system. "Just as we already test the progress of our students and our schools," Harris said, "so too should we test our teachers." He noted gleefully that the Liberals were opposed to the plan. "Once again," he charged, "Mr. McGuinty has listened to the demands of union bosses instead of the wishes of parents across the province." To support his claim of broad popular support for the program, Harris released the results of a recent poll commissioned by his party showing that 71 per cent of the public answered in the affirmative when asked this question, "Would you favour or oppose requiring that all teachers in the province be regularly tested to ensure that they are qualified and up-to-date?"13 If the poll was accurate, teacher testing was a coveted 'wedge' issue that pitted the Conservatives on one side - the side most of the public supported - and the two Opposition parties on the other.

Predictably, the teacher federations reacted angrily to Harris's Oakville announcement. "It's appalling," said Liz Barkley, president of the Ontario Teachers' Federation. "Once again, he's showing absolute disdain for the profession." Phyllis Benedict, president of the Elementary Teachers' Federation of Ontario (ETFO), was equally critical. "This is a diversionary tactic," she suggested, "because he's out there getting hammered on education." This outspoken opposition may have played right into Harris's hands. His confrontational electioneering approach required enemies that he could goad into outrage. As Robert Sheppard of Maclean's noted in mid-campaign, "having a foil suits the Harris style." 14 Less welcome to the PCs was the candour of the Ontario College of Teachers spokesperson, Denys Giguere. When asked if the Premier's suggested timelines for implementation were attainable, he replied, "[W]e have no specifics so it's very difficult for us to know if this is realistic or not." He went on to point out that a College regulation already required Ontario teachers to possess specific teaching qualifications, and that school boards were currently empowered to evaluate teacher performance in the classroom. ${ }^{15}$ The OCT representative's comments indicated problems 
ahead for the policy's implementation, but evidently it did not resonate with a large majority of the province's voters. On election day, the ruling Progressive Conservatives were re-elected with 59 seats out of 103 total, based upon 45.1 per cent of the popular vote. ${ }^{16}$ Their share of the total votes cast was actually up, marginally, from the 1995 election. By the rules of the game in a three-way race, Mike Harris could claim a popular mandate for his teacher-testing policy.

\section{Refining The Policy}

The Conservative government did suffer some losses in the campaign, notably the defeat of Education Minister Dave Johnson in his own riding. In part, at least, the upset was due to the intervention of hundreds of teacher canvassers, who had targeted Johnson for defeat. This result did not signal a change of direction, however. His successor, Janet Ecker, stated firmly on July 17 that mandatory teacher testing remained a government priority. ${ }^{17}$ The PC policy continued to be a major headache for the Ontario College of Teachers, still struggling to establish its credibility with the public and its own members. In the pages of the June, 1999 issue of Professionally Speaking, the OCT's own journal, Donna Marie Kennedy emphatically stated that the new government policy had caught her and the rest of the College Council completely off guard. When alerted in April to expect a major government announcement, they had "hoped this would be an announcement that the government would, as the College had requested, fund 2,000 more spaces in Ontario's faculties of education to help deal with the serious shortage of qualified teachers in this province." Kennedy, the Council chair, stressed that "neither the College, nor Council, had been consulted" on the proposal for mandatory teacher re-certification every three to five years. She conceded the government had stated its intention to consult with the College of Teachers, but perhaps fearing the Premier's habit of moving quickly from speculation to implementation, she emphasized the OCT's practice of making "consultation with both its members and the public a high priority." ${ }^{18}$ Behind the scenes, College staff began to research teacher testing in other jurisdictions around the world.

Premier Harris kept up the heat on teachers with comments to the press on the occasion of a three-day caucus retreat in early September. Classroom teachers judged incompetent on the tests would lose their jobs, he stated, unless they could quickly get up to standard, adding that "no teacher has anything to fear unless they are incompetent." ${ }^{19} \mathrm{~A}$ few weeks later the Liberal Opposition Leader, Dalton McGuinty, accused the premier of teacher baiting, while at the same time ignoring evidence that teacher testing had failed in several U.S. states where it had been tried. "Testing teachers does little to improve the quality of education," he noted. "But it does allow him to continue hammering his favourite interest group." ${ }^{20}$ In a more subtle way, the College of Teachers seemed to send out the same message. In a major article entitled, "No Clear Answers on Many Complex Issues That Surround Teacher Re-certification" in the September, 1999 issue of Professionally Speaking, it reviewed some of the major research into the effectiveness of teacher testing. In one typical study, the evidence clearly seemed to indicate that passing the test "does not guarantee that an individual will become a satisfactory 
teacher." The mastery of factual knowledge could be tested; assessing skills and aptitude for effective classroom instruction was quite another matter. The article went on to note that some jurisdictions, notably the province of Alberta, had opted for a different model, namely individualized professional development plans, monitored on an annual basis. ${ }^{21}$ Without doubt, the College of Teachers feared it would be asked to implement a simplistic, yet heavy-handed policy of teacher testing that would alienate its teacher members, while doing little to improve the quality of education.

Finally, on November 10, 1999, Janet Ecker wrote to Donna Marie Kennedy, chair of the Governing Council of the Ontario College of Teachers, formally requesting "the advice of the College on how to implement a program for teacher testing which is cost effective." 22 The Education Minister reiterated that, "the Ontario government has made a commitment to require teachers to participate in a teacher testing program," and restated the Premier's pledge that the first stage of implementation would commence in June, 2000. Ecker set out five parameters for the policy: “(1) regular assessment of teachers' knowledge and skills; (2) methodologies which include both written and other assessment techniques; (3) a link to re-certification; (4) remediation for those who fail assessments; and (5) de-certification as a consequence if remediation is unsuccessful." From the OCT's point of view, two items provided a glimmer of hope. The reference to "knowledge and skills," in point one, and the reference to "written and other assessment techniques," in point two, seemed to indicate that the Minister of Education, at least, was aware that an old-fashioned pen-and-paper exam, or even an electronically scored multiple-choice test, would not meet the government's twin goals of quality and accountability. That was the good news. The bad news was that the Minister, while encouraging the OCT to consult with faculties of education, teacher federations and "other education partners," requested the College to provide its advice by December 31, 1999, less than two months away. The PC government had taken seven months before asking for advice and now wanted its answer in seven weeks.

Janet Ecker addressed the College Council personally on November 18, reiterating both her commitment to teacher testing and her need for a College response by December 31. Notwithstanding the Minister's determination, the College of Teachers stared her down. In a letter of reply dated November 26, Donna Marie Kennedy stated firmly that the time-frame adopted by her Council to produce its report would "not allow the College to provide you with advice by December 31st." There was a need to digest the research material already accumulated, to consult the interested stakeholders - including the College's own teacher membership - and to draft, revise and finalize a set of recommendations. With "a structured consultation process" scheduled for February and March, Kennedy was implying that the final report could not be expected before April. ${ }^{23}$ Having encouraged the OCT to consult widely, there was little Ecker could do but wait. She, too, was feeling political heat because the backroom political operatives in the Premier's Office expected some concrete action on the teacher-testing file before the end of June. In that way, Harris's election commitment to begin teacher testing by June, 2000 could be redeemed as another promise kept.

On February 9, the College released a 100-page preliminary "consultation document incorporating the research on teacher testing, describing the Ontario context 
and providing a wide range of options emerging from the research." In all, there were 22 "Options" designed to address the five parameters of teacher testing addressed in Ecker's letter of November 10. Significantly, not one of them proposed an actual test. According to Kennedy, in comments made to a reporter, this was because they couldn't find a jurisdiction where teacher tests proved successful. "In the research we have done, and it was extensive," she noted, "we couldn't put an option out proposing teacher testing because we had no background information." From February 14 to March 3, the College hosted a series of structured sessions with 42 stakeholder groups, ranging from the Canadian Federation of Independent Business, to the Catholic Principals' Council of Ontario, to Parent Network Ontario, to the Association des enseignantes et des enseignants franco-ontariens. Individuals were encouraged to provide feedback through fax, e-mail and website communication. An ad hoc committee of the College Council worked feverishly to assimilate the information, formulate a series of recommendations and tie them together into a credible package. ${ }^{24}$ The final report, with its 15 specific recommendations, was made public and delivered to the Minister of Education on April 13, 2000. ${ }^{25}$

Surprisingly, the College recommended an entry-to-the-profession test, euphemistically referred to as "a written assessment of knowledge related to Ontario curriculum and education legislation and policy appropriate for beginning teachers prior to entrance to the profession in Ontario." They further recommended that its cost be covered by "the fee charged to the candidates." Once these novices were employed by a board of education, the College recommended a two-year induction program to ease their transition into the profession. For experienced teachers, the report urged the Ministry of Education to standardize the teacher performance appraisals conducted by boards across the province. It recommended that employed teachers should each prepare a professional growth plan and maintain a teaching portfolio to highlight ongoing professional learning. Both of these items were to be linked to the performance appraisal process. Once every five years, each teacher would report the contents of their portfolio to the College of Teachers. Under this set of recommendations, only beginning teachers would be tested in the traditional way, while all employed teachers would undergo periodic performance appraisals by their boards, and be expected to develop a professional growth plan and keep a teaching portfolio. Would this be enough for the PC government, committed to a teacher-testing program that should begin in June, 2000 ? It met cautious approval from one of the major teacher federations, ETFO representing the public elementary teachers, whose President Phyllis Benedict stated, "We welcome the College's contribution to the 'teacher testing' debate." ${ }^{\prime 6}$

On May 11, Janet Ecker released details of her government's new policy, dubbed the "Ontario Teacher Testing Program." It followed the recommendations of the College of Teachers report quite closely. New teachers would be required to pass a test before they could be certified to teach in Ontario. An induction program for new teachers was also promised. These two elements paralleled the OCT's report almost exactly. The government toughened up the College's recommendations regarding professional growth plans and portfolios. "To be re-certified," the Education Ministry press release stated, "teachers will have to take a set number of required courses and pass related 
tests and assessments that will help them keep their knowledge, skills and abilities upto-date." The College's recommendation of a five-year cycle for this professional learning process was retained, however. The Minister of Education also accepted the College's recommendation for consistent, province-wide standards for teacher performance appraisal by boards and principals, but added a provision for "increased opportunities for parents and students to evaluate teachers." Ecker also pledged to develop "a new review process to determine if teachers who are not meeting the standards should have their certification removed." In this regard, the OCT report had simply recommended that employers be required to notify the College if a teacher was dismissed for reasons of incompetence. Finally, in order to get moving on something by the summer of 2000, the Minister announced that, effective in June, all teachers trained in a language other than English or French would be required to "pass an oral and written language test before entering the teaching profession in Ontario." ${ }^{27}$

One of the most significant differences between the OCT report and the Ministry of Education press release was one of tone. The College document was respectful of its teacher members, whereas the Ministry's statement contained wording and provisions that might be construed as implying teachers could not be trusted to act professionally. Perhaps the PC government wanted to polarize the public debate. At any rate, the heads of the teacher federations predictably voiced strident opposition to the new policy. "It assumes we don't keep up to date and do our jobs well unless we are regularly beaten over the head," complained Phyllis Benedict, president of ETFO, Jim Smith, OECTA president, charged that the proposed re-certification requirements would put all teachers on "perpetual probation." Earl Manners, president of OSSTF, predicted the teacher-testing polices would create a "brain drain" of the best teachers to the United States. By contrast Margaret Wilson, registrar of the Ontario College of Teachers, took a middle position. "A lot of the things under discussion are appearing under different guises in much of the English-speaking world," she pointed out, "as people are grappling with how to deal with the quality issue and the competence issue." Having given its advice, the OCT would now be asked to implement much of the new policy. From its point of view, the time for polarized opposition was over. The Education Minister, however, continued to sell the new policy rhetorically as a "made-in-Ontario teacher testing program" designed to "ensure all teachers are up-to-date in their skills and training." ${ }^{28}$ More conflict seemed inevitable.

\section{Implementing the Policy}

At the elite political level, the Conservative government's teacher-testing policy was now in place. With the exception of the language proficiency test for prospective teachers educated in languages other than English or French, however, implementation dates were still some time hence. The mandatory re-certification cycle for experienced teachers was slated to begin in the Fall of 2001, as was the system of province-wide standards for performance appraisal of teachers by school boards and principals. Finally, the entry-to-the-profession test for initial certification was to be implemented for the first time at the end of the 2001-2002 academic year. Target dates for the promised certifi- 
cation review process (to dismiss incompetent teachers) and induction program for new teachers were not specified. ${ }^{29}$ Now, the focus shifted from campaign speeches, legislative debates and ministry press conferences to a more subterranean level involving key civil servants, interest-group spokespersons and other attentive education stakeholders. At times, the wrangling spilled over into the public arena, but often the action was out of the media spotlight. Yet, all the major players realized that many decisions of great importance concerning the actual implementation of the announced programs still had to be made. The scope for determined lobbying was still broad. And there was always the next election.

At Queen's Park, the Ministry of Education established the Ontario Teacher Testing Project, a new department within the bureaucracy. Hiring qualified personnel to manage the program occupied several weeks. Perhaps belatedly, the Ministry moved to establish periodic consultations on the issue with those groups it frequently referred to as its education partners: parent groups, school board associations, the faculties of education and the College of Teachers. Contact with teacher federations was less frequent, and when it occurred, more confrontational. Little of substance in the area of teacher testing happened for the rest of 2000, other than the formal implementation by the OCT, beginning in September, of the language proficiency test for new applicants whose teacher training had been in a language other than English or French. The College of Teachers continued to consult as well, inviting representatives of the faculties of education to a day-long meeting in Toronto that Fall to brainstorm ideas about the possible contents and format of an entry-to-the-profession test. Not surprisingly, many of the faculty representatives were less than enthusiastic, judging the proposal for a qualifying test of graduating teacher candidates to be redundant at best and dismissive of the value of their B.Ed. programs, at worst. ${ }^{30}$

At a joint meeting of the Ontario Teachers' Federation and Ontario Association of Deans of Education (OADE) in the spring of 2001, Paul Anthony, the Ministry of Education's new Director of Policy and Standards for the Ontario Teacher Testing Project, revealed that the implementation of the program had been divided into two phases. With the language proficiency test farmed out to the College of Teachers, the Ministry was focussing on three priorities: the initial certification test for beginning teachers, the "certification maintenance," or re-certification, process for experienced teachers and the standardized classroom performance appraisal framework. Left for a second phase would be the two-year induction program for new teachers, the school quality assurance program and a mechanism for recognizing teaching excellence. A month later, at a joint meeting of the Ministry of Education and the provincial faculties of education, Anthony reported that he and his colleagues had put together a working document to transform the College of Teachers' standards of practice into "competency statements" that would guide the implementation of Phase Two. The Ministry had by this time established consultative workgroups involving representatives of the OCT, principals' associations, directors and supervisory officers and teacher federations. OECTA, representing all Catholic teachers, and OSSTF, representing the public secondary teachers, had boycotted these groups, but ETFO, voice of the public elementary instructors, reluctantly agreed to take part. To develop the actual evaluation 
instrument for the new-teacher qualifying test, the Minister had issued a Request for Proposals on March 14, 2001, inviting bidders from the public or private sector to submit their designs. ${ }^{31}$

Things began to heat up again in June, 2001 when the PC government formally announced its intention to impose mandatory re-certification and compulsory professional learning on teachers through a bill rather disingenuously titled the "Stability and Excellence in Education Act." Bill 80 required every certified Ontario teacher to complete a professional learning program of 14 courses every five years, with each course lasting a minimum of five hours and including some type of written assessment. Seven of the courses had to be in specific core areas, namely one each of curriculum, student assessment, special education, teaching strategies, classroom management and leadership, use of technology, and communicating with parents and students. The other seven could be taken in those or other areas of teacher interest. The program was to be administered by the College of Teachers, which would pre-approve courses and course providers and keep official records of each teacher's course completions. Teachers who failed to complete 14 courses over the five-year cycle would be de-certified and lose their license to teach. Introduced in the legislature in early June, Bill 80 was passed into law on June $28 .^{32}$

Believed to be the first law in Canada to enact mandatory professional development on publicly-employed teachers, the bill was controversial. Phyllis Benedict, president of ETFO, noted that teachers already voluntarily engaged in professional upgrading on a regular basis, while at the same time the provincial government had cut the funding and time available for formal professional development days. "Mandatory professional development and teacher testing," she declared, "denies teachers' professionalism, is redundant and insulting." On the day the bill was finally passed, she predicted her members would refuse to take the required courses. Liz Sandals, the head of the Ontario Public School Boards Association, accused the government of introducing a double standard. Since many of the instructors employed by private schools were uncertified, they would not have to undergo the costly and time-consuming process of perpetual re-certification. Perhaps the stiffest initial opposition came from an unexpected source, the Ontario College of Teachers. In a statement issued by the OCT's Toronto office, the College chair, Larry Capstick, denounced the plan as a rushed job that would be expensive to administer. He did not mince his words:

It is unrealistic to expect that this program that ties teacher licensing to completion of professional development can be successfully launched by September. The government is demanding that in a little over two months, with no clear funding commitments from the Ministry of Education related to implementation or maintenance, the College puts in place a re-certification program for 40,000 classroom teachers - one third of teachers in publicly funded schools. When we talk about re-certification, we're talking about people's licences to teach - their ability to earn a living. Such a program must be driven by the realities of setting up a complex system that is administratively feasible, publicly credible, professionally acceptable, legally defensible and economically feasible. 
Capstick's passionately blunt statement accurately predicted nearly all the subsequent difficulties associated with implementing the government's Professional Learning Program (PLP). ${ }^{33}$

Unlike in 1999, this time Ecker was ready for the opposition of the College of Teachers. As Capstick and the OCT registrar, Joe Atkinson, acknowledged in a general letter to all College Members on August 13, 2001, "Bill 80 requires the College to begin to implement the program this September." A sizable minority of the members of the College Council were already government appointees. To further guarantee its influence on the College's administration of the mandatory teacher re-certification program, the legislation further provided for the establishment of a new Professional Learning Committee made up of four members of the College Council and two College members at large (i.e. not members of the elected council). A provision of the legislation gave the Minister of Education authority to name up to five additional members to the special committee. The message was clear: toe the line, or else. Overt opposition by the OCT to the government's professional learning program ended with the passage of the legislation in late June, 2001. From that point on, the College bent its efforts to harmonizing the government's mandatory re-certification initiative with the other assessment priorities it had identified in its April, 2000 report to this same Minister. ${ }^{34}$

In October, Ecker introduced a second bill, the "Quality in the Classroom Act," to address the other two components of the first phase of the government's teacher-testing program. The first purpose of Bill 110 was to put in place a province-wide performance review system for teachers. Under the act, new teachers would be evaluated twice a year during their first two years, while experienced teachers would be evaluated once every three years, in each case by their principal or vice-principal. Under planned regulations, the review process would have four ratings for teacher performance: exemplary, good, satisfactory and unsatisfactory. Teachers whose rating was deemed to be unsatisfactory would initially receive support to improve their classroom performance, but a continued rating of unsatisfactory could lead to dismissal for incompetence. Input would be solicited from parents and senior students, although their feedback could not directly result in the dismissal of a teacher. In her statements explaining the legislation, the Minister cited the support of three interest groups for this part of the teacher testing program: the Ontario Federation of Home and School Associations, the Council of Directors of Education and the Ontario Principals' Council. ${ }^{35}$

A second purpose of Bill 110 was to establish a qualifying test to "measure new teachers' knowledge of the curriculum and teaching strategies." Beginning in the spring of 2002, candidates would have to pass the qualifying test to obtain their teaching certificate from the Ontario College of Teachers. The purpose of this initiative, Ecker told the legislature, was "to ensure that those who want to teach in Ontario have the necessary skills and knowledge required before they become certified." Earlier in the year, the government had announced that the winner of the bidding competition to design and administer the entry-to-the-profession test was a consortium of the Ontario Principals' Council and a giant American firm, Educational Testing Service of Princeton, 
New Jersey. Their evaluation instrument was a combination of multiple choice questions and short-answer questions related to case studies. Field testing was being planned prior to the first official administration of the test, slated for April or May, 2002. ${ }^{36}$

Reaction by the teacher federations to Bill 110 was relatively muted, but only because they were already in full mutiny over Bill 80, which had instituted mandatory professional development and periodic re-certification. Phyllis Benedict, head of the public elementary teachers, had said in June that her members would refuse to take the courses. Of the three big unions, hers was traditionally the most moderate. Later in the summer, the public secondary teachers made their position clear with this statement: "OSSTF will not participate in any way in the government's recertification initiative.... Instead, OSSTF will continue to offer our own quality professional development, conferences and resources for members." A few weeks later, OECTA reiterated the firm opposition of English-speaking Catholic teachers to re-certification, even urging "that members who receive letters from the College of Teachers informing them that they are in the first cohort for recertification return these letters to the College of Teachers." Opposition from the large teacher federations was nothing new to the PC government. In fact, with the College of Teachers now hard at work administering the PLP, with the Ontario Principals' Council serving as co-designer of the new teacher qualifying test, and with various parent groups supporting the Teacher Performance Appraisal (TPA) program, things were looking more positive for the teacher-testing policy than they had in a while. As a new Ministry pamphlet issued for 2002 put it, "With these initiatives to support our teachers - ongoing professional learning, ongoing performance appraisals, and the qualifying test for new teachers - parents can be assured that their children are receiving a high-quality education, provided by the best-qualified and most highly skilled professionals in Canada." The optimism proved premature. As OECTA president Kathy McVean had said in September, 2001, "we are convinced that organized opposition will cause this unwieldy, unjust model to collapse." 37 Clearly, a very public test of wills and political resources between organized teachers and a determined provincial government was now unavoidable.

\section{Resistance to Re-certification}

Loyal federation members returned their PLP letters to the College of Teachers by the thousands. Hundreds of others, who were not among the 40,000 randomly selected for the first cohort, took the time to send a protest letter to the OCT, voicing their disapproval of the government's unprecedented re-certification policy. The government was taken by surprise at the vehemence of the protest, but it professed indifference. "I'm really confident at the end of the day, we'll get support," said Mike Harris. His Education Minister blamed "misinformation" emanating from the federations' leaders. "I'm always concerned," Janet Ecker declared, "when some people in teachers unions want to pick fights on the backs of kids." Garfield Dunlop, Ecker's parliamentary assistant, dismissed Phyllis Benedict's prediction that dissatisfaction with the re-certification policy would exacerbate the impending teacher shortage. "Lots of people want to be teachers," he insisted. "It's a well-paid profession with plenty of holiday time." Meanwhile, at 
the offices of the College of Teachers, bringing order to chaos was the order of the day. On top of its normal duties, the regulatory body had to launch its legislatively mandated Professional Learning Committee, set up the administrative machinery to keep track of individual professional development records for well over 100,000 teachers, then find and approve hundreds of course providers, not to mention hire and orient new staffers, all while coping with a disgruntled membership convinced that it had betrayed them. In that regard, teachers were soon made aware that the provincial government had used its legislated prerogative to appoint three members directly to the Professional Learning Committee, representing one-third of the total membership of this vital coordinating body. ${ }^{38}$ Government pressure on the College of Teachers to fully implement the mandatory re-certification program would obviously continue, so long as the Conservatives were in office.

The teacher federations continued to operate independently, but there was a degree of solidarity and collaboration reminiscent of the two-week province-wide teacher walkout of 1997. On November 6, 2001, the Ontario Secondary School Teachers Federation declared itself "totally opposed to the government's and to the College of Teachers' re-certification program," and urged its members to "take a firm and collective stand opposing re-certification." It pledged that it would "not apply for provider status for the Professional Learning Program," but would "continue to offer quality PD programs for members." It advised its membership to "continue to take courses and participate in PD days and member-chosen learning," but to "refuse to complete any assessments that will count for the College's PLP," to "refuse to apply or agree to be providers of any PLP courses," and to "not enrol in any programs offered exclusively as PLPcourses." While refusing to have anything to do with the mandated re-certification program, OSSTF declared itself resolutely in favour of "ongoing self-directed teacher learning.

In a similar vein, the Elementary Teachers Federation of Ontario sought to make clear that its opposition to the government's PLP initiative did not signify opposition to professional growth. "ETFO members have always done professional development," it declared in etfo voice, "the professional development we know meets our needs and the needs of the children in our classroom." It dismissed the government plan as "permanent probation." To keep the pressure on the Ministry, ETFO advised its members to "continue to take the professional development you need.... Just don't take the PLP courses approved by the Ontario College of Teachers for recertification." It further urged the membership to "refuse to complete the evaluation component of professional development programs you are required to attend," and to "not participate in the development, delivery, or evaluation of any recertification programs." Beyond these immediate professional concerns, ETFO members were asked to "talk to your friends, neighbours, and the parents of your students" about the teachers' perspective, to "return Professionally Speaking to the Ontario College of Teachers," to "tell your elected politicians - provincial and school board - how you feel about the government's recertification plan," and to take their concerns to the top of the ladder by writing directly to the Minister of Education. As an example of their more overt political action, Toronto-area ETFO members staged a protest march and demonstration in front of the OCT offices 
in June, 2002 to coincide with the College's annual meeting, at which their leader, Phyllis Benedict, presented a petition against re-certification signed by some 35,000 of ETFO's 65,000 members. In the etfo voice article entitled "Strategies for Success," members were reminded of the need to keep informed, stay united and brace for a long fight. "We have the government's attention," the article noted. "But we need to do more." 40 The next election was still many months away, but in the meantime, the members were urged to do all that was legally allowed to resist what they perceived to be an unwise policy.

Possibly the most radical of the federations on this issue was the Ontario English Catholic Teachers Association, which publicly touted its "re-certification resistance campaign." OECTA forthrightly declared that its approach was a total "boycott" of the Professional Learning Program initiative. In the Windsor, Ontario area, this even included a refusal by its members to accept student teachers because the local Faculty of Education was listed by the Ontario College of Teachers as a PLP provider. OECTA promised it would be "defending and supporting professionally and legally any member who is disciplined by the College of Teachers over re-certification." It was very proactive in contacting organizations listed on the College of Teachers website as PLP providers, seeking to dissuade them from following through. "While virtually every public and francophone school board is a provider," OECTA stated, "the largest Catholic school boards in the province are not ... an indication of the penetration of our message of resistance to re-certification." Noting that the OCT had expected to have more than 1,300 accredited re-certification providers, the Catholic federation reported that, as of October, only 353 were listed on the College website - although that was "353 providers too many" for the OECTA leadership. In an issue of Agenda totally devoted to the "Re-Certification" controversy, OECTA noted the annual membership fee for the Ontario College of Teachers would rise by $\$ 35$ to $\$ 139$ on January 1, 2003, a 34 per cent hike "to finance the rising cost of the bureaucracy that will administer teacher re-certification." OECTA was openly hostile to the OCT, itself. "As the principal agent of implementation for teacher testing, the College is discredited," 41 it declared in Agenda.

The Ontario College of Teachers fought back with deeds and words. It worked feverishly to get the PLP initiative off the ground, establishing guidelines, wooing potential providers and vetting proposed courses. On its website, through the pages of Professionally Speaking, and via mass mailings to members, the OCT did its best to paint the re-certification program in a positive light, and thereby induce teacher compliance. Its July 4, 2002 letter to the thousands of College members not covered in the first cycle was typical of its upbeat message. "The Professional Learning Program is not teacher testing," insisted Larry Capstick and Joe Atkinson, both of whom had now become cheerleaders for the mandatory professional development initiative. "It is a program of ongoing professional learning designed by you, the individual educator, from a list of opportunities that relate to your professional needs." Behind the velvet tone, there was a hint of iron. Noting that "the College has been asked what will happen if a member does not participate in the PLP," the letter was clear. If at the end of the five-year cycle "the member still has not completed PLP requirements, the Col- 
lege will suspend the member's teaching certificate and the member will not be able to hold a teaching position in Ontario's publicly funded schools." College personnel preferred the carrot to the stick, however. By September, 2003, an article in Professionally Speaking declared that "the PLP is fully functional, growing and gathering momentum.” Internal politics within the College Council helped to explain the OCT's evolution on the issue. According to an OSSTF report, by 2003 "the principals' representative and supervisory officers' representative worked with government appointees" to block the influence of the "teacher caucus." 42 In other words, a bare majority of members of the college's governing Council was now pro-government, and thus on this issue, anti-teacher.

For the most part, the PC government was happy to let the College of Teachers take the heat from the teacher federations. Janet Ecker did send out an opinion article that various newspapers carried, in which she pointed out that the Royal Commission on Learning, appointed by Bob Rae's NDP government, had called for "mandatory professional development" in its 1995 report. Her successor as Minister of Education, Elizabeth Witmer, began her tenure by inviting suggestions for improving the PLP, but retreated when most of the input called for its abolition. "When I initially made my request," she explained, "I was looking for some suggestions that could be achieved within the legislative framework." Under Ecker, the provincial government had finally acceded to the College's request for a special grant of $\$ 8$ million to cover start-up costs for the PLP. From that point on, however, the OCT was to meet the costs of the program from membership fees, hence the $\$ 35$ increase so resented by the teachers. In another provocative move, the Ministry of Education withdrew $\$ 1.7$ million that it normally contributed to the annual summer institutes run under the auspices of the Ontario Teachers' Federation. The government was miffed that the OTF refused to apply for PLP provider status for these popular professional development programs. By 2003, both the Conservative government and the teacher federations understood that the crucial battle to decide the future of the re-certification program would be fought, not between them directly, but on the election campaign trail. ${ }^{43}$

\section{Resistance to the Qualifying Test}

The other publicly controversial part of the Conservative government's teacher-testing program was the entry-to-the-profession, or qualifying test, although the level of conflict here never reached the vitriolic heights of the re-certification battle. True, an entry test had been one of the fifteen recommendations of the Ontario College of Teachers in its "advice" to the Minister of Education in April, 2000, but the OCT was now otherwise occupied with the PLP controversy. The teacher federations were adamantly opposed, but they were less directly engaged in this issue, as compared to mandatory re-certification. Naturally, the teacher candidates themselves were opposed to a high-stakes, one-shot exam where a bad day could keep them from achieving their career goal, despite the successful completion of a challenging Bachelor of Education program. One other organization weighed in on the negative side, namely the Ontario Association of Deans of Education. While the dependence of the faculties of education 
on provincial funding meant they had to prudently pick their spots, the elevated prestige that came with their titles lent a definite air of gravitas to their collective pronouncements. And the Deans were not happy with the imposition of a standardized test to assure the public that their graduates were qualified to teach. The Bachelor of Education degree, in their view, already signified mastery of such topics as provincial curriculum, teaching strategies, learning theory, assessment methods, classroom management, use of technology and special needs instruction.

At Ontario faculties of education, student teachers receive intensive classroom instruction, practice-teaching experience, and comprehensive evaluations of their performance on these important subjects. They cannot be assessed effectively in a single four-hour 'licensing' exam. Nor can a multiple-choice test meaningfully measure such crucial teaching qualities as dedication, leadership, sensitivity, reflective thinking, ability to communicate, and social awareness ... themes also addressed in teacher-education programs.

The Deans were determined to do whatever they could do to dissuade the government from proceeding with a costly, and in their view redundant, qualifying test. ${ }^{44}$

Another educational interest group jumped in on the government's side. The Ontario Principals' Council (OPC) was the professional body representing some 5000 principals and vice-principals employed in the province's publicly funded, non-Catholic elementary and secondary schools. Established only in 1998, it was the direct result of the Harris government's decision that principals and vice-principals must not be members of the teacher federations. In possession of polling data they had commissioned from IpsosReid that indicated about 80 per cent of Ontarians favoured a pre-service qualifying teacher test, the OPC was interested in establishing its credibility with the public and the Harris government. Furthermore, as they noted in their own journal, The Register, they had "a vested interest" in the success of the qualifying test, since they were held accountable for the performance of the teachers in their schools. When no organization of significance responded to the Education Ministry's request for proposals, the Ontario Principals' Council decided to get involved. Lacking experience in the large-scale design and development of standardized mass tests themselves, they sought out a qualified partner. Here is how they justified partnering with an American-based multinational corporation to create the government's made-in-Ontario test. "Our search led us to the Educational Testing Service (ETS) in Princeton," they stated in The Register, "the largest testing and measurement organization in existence, considered the most credible testing authority in the world. Operating in 181 countries, ETS develops and annually administers more than 11 million tests worldwide." ETS brought its vast experience and technical knowledge to the table, while OPC supplied local knowledge of Ontario's legislation and school system. Their joint bid received Ministry approval in May, 2001. ${ }^{45}$

Bill 110, officially the "Quality in the Classroom Act," did not receive final legislative approval till December 12, 2001. Moreover, the enacting regulations were not formally proclaimed for several more weeks. Although the ETS-OPC team had begun their work months earlier, nevertheless, much about the test could not be finalized until 
these legal details were confirmed. The result was a chaotic dash to implementation. Both Ecker and Harris were insistent that the graduating class of 2001-2002 would inaugurate this key aspect of their teacher-testing program. Everyone else connected to the qualifying test was urging them to declare this first attempt a field test only, and not hold the graduating class of student-teachers ransom to the inevitable start-up snafus. OADE was joined by the College of Teachers in "respectfully but urgently" requesting the PC government to reverse its decision to have the test "count" in 2002. In their view, "the 2002 test scores should be used by ETS to properly validate the test for next year." Suzanne Herbert, the Deputy Minister of Education, took only four days to reject the request. By this time, even the Ontario Principals' Council was urging that the April, 2002 test it had co-designed be considered a pilot. As the Education Deans stated in their public letter of March 11, 2002, "a controversial test delivered within a problematic time frame in an atmosphere of uncertainty will undermine the purpose for which it was intended." The Deans even dared to compare the OTQT to another political hot potato, the PLP. "The same thing happened with the new teacher recertification program" they maintained. "Established in haste, imposed on teachers, it has encountered considerable resistance." Those most directly affected by the delays and confusion, the Education students across the province, planned their own form of resistance. Spearheaded by the OISE/University of Toronto Student Teachers' Union, the Bachelor of Education students formed a 'Stop the Test Organizing Committee.' On March 27, 2002, they held a protest march and rally at Queen's Park, attended by hundreds of teacher candidates who bussed in from around the province. Prominent non-student speakers included Earl Manners of OSSTF, Kathy McVean of OECTA, Rosario Marchese, the NDP education critic and Gerard Kennedy, the Liberals' shadow minister for education. And still the government held firm. ${ }^{46}$

Firm, that is, until Ernie Eves replaced the retiring Mike Harris as Conservative Premier in March, 2002, and Elizabeth Witmer moved into the post of Minister of Education. Suddenly, there was a softer tone at the other end of the debate. On April 23 , only four days before the four-hour test would be written by over 7000 graduating student teachers, Witmer announced that the test would go on, but that it would not count this year. The teacher candidates would have to show up to write the test, but the results would be used as a pilot only, to fine-tune the process for the next year. The Toronto Star reporters who broke the story saw the move by Witmer as "a clear signal that peace with the province's teachers is a priority of Premier Ernie Eves." The news was welcomed by the Ontario Principals' Council, the College of Teachers and the Ontario Association of Deans of Education. While the Ontario student teachers did not achieve their ultimate goal - terminating the idea of a qualifying test altogether - at least they won their most pressing point. No one in the 2002 graduating class would fail to be certified because they flunked the first qualifying test. Next year was another story, however. With more time to work out the bugs, and two pilot tests in 2002 (April 27 and November 23), the ETS-OPC consortium, aided by the Ministry of Education, was able to administer the April 5, 2003 qualifying test without significant opposition. On June 3, Elizabeth Witmer proudly announced that 97 per cent of 
Ontario's teacher candidates $(8,329$ of 8,523$)$ had passed the first official Ontario Teacher Qualifying Test. "Now parents can definitely be assured that new teachers entering the classroom have a solid foundation of knowledge and skills to help students achieve," she asserted. Any of the 200 or so unsuccessful candidates were welcome to try again at the next OTQT date, which was already scheduled for July 12, 2003. Whether the public assurance was worth the tab was unclear, however. The OTQT had cost $\$ 8$ million to set up and would require over $\$ 10$ million to administer on an annual basis. Whether the qualifying test would survive the next election was also hard to determine. ${ }^{47}$

\section{Input from the Voters}

While the Ontario College of Teachers moved ahead with its planned implementation of the Professional Learning Program, the teacher federations directed more and more of their attention to the upcoming provincial election, widely expected for the Spring or Fall of 2003. They did so with some reason for optimism. In the past three elections, they had twice been significant contributors to the defeat of incumbent administrations by campaigning against the David Peterson Liberals in 1990 and by refusing to help the Bob Rae New Democrats in $1995 .{ }^{48}$ The unexpected re-election of the Mike Harris PCs in 1999, despite the organized teachers' best efforts, had been a bitter pill to swallow, however. The replacement of Harris in March, 2002 with his modestly kinder and gentler ex-Finance Minister, Ernie Eves, did not deter the federations from their objective, particularly when the new Tory government responded to a string of lockouts, strikes and work-to-rule conflicts across Ontario with legislation that, if passed, would permanently ban all such disruptions to the school year. When Eves announced the provincial vote would be held on October 2, 2003, the teacher federations were ready with campaign plans and communication strategies of their own to defeat what they continued to call the Harris-Eves government. They were prepared to throw their full organizational muscle behind whichever Opposition candidate - Liberal or New Democrat - had the best chance of defeating the Government standard-bearer. As one of their glossy election booklets proclaimed, "This time the Tories must Go!" 49

The federations did not make the mistake of overtly raising the teacher-testing issue in the election campaign. They were aware of polling data which showed that a majority of Ontarians supported the idea in principle, especially if the survey question avoided the complexities of actual implementation. Their role was largely behind the scenes in 2003, motivating their own membership to spread the anti-PC message among neighbours, friends and family, to volunteer as canvassers for local Opposition candidates, and above all to vote against the Government on election day. A series of province-wide polls showed the Liberals were poised to defeat the Conservatives, with the NDP lagging far behind. Although many federation activists felt a closer affinity to the labour-oriented NDP, the politics of strategic voting limited organized teacher support of NDP candidates to those relatively few ridings where they had incumbent MPPs, or fielded the strongest challenger to a sitting PC member. The Liberals did 
not go out of their way, publicly, to court the teacher vote. In fact, Dalton McGuinty seemed at times to distance himself from them. "I've met many teachers who have said they don't believe in standardized tests," he stated early in the campaign. "Well I do. And we're going to keep them, and we're going to improve test scores." It was enough for the leaders of the teacher unions that McGuinty's Liberals were pledging to withdraw the teacher re-certification legislation, to reform the Ontario College of Teachers, and to oppose the Tories' proposed ban on educational strikes and lockouts. They much preferred McGuinty's promise to "respect" teachers over Eves' commitment to restore "peace in the classroom" by a heavy-handed prohibition of all labour stoppages in the schools of Ontario. ${ }^{50}$

The election campaign was largely fought on issues other than education - health care, for example, as well as the security of the electric power supply, tax cuts and budget deficits. The Conservative strategy, a repeat of 1999, was to focus attention on leadership. But the new Premier, Ernie Eves, was not Mike Harris, and the Dalton McGuinty of 2003 projected a much more confident air than he had as a rookie Opposition leader in 1999. The televised leaders' debate came out a draw and this time the Tory attack ads on the Liberal chieftain seemed to backfire. When the votes were finally counted on the night of October 2, the Liberals held a solid majority of the seats, based on 46 per cent of the popular vote. The eight-year reign of the Conservatives was now over. But what did the election result mean for subsequent education policy, and in particular for the cluster of initiatives dubbed by the PCs the Ontario Teacher Testing Program? It was widely anticipated by those in the know that the Liberals would closet themselves with the provincial account books for a few days, pronounce themselves shocked at the wretched state of the budget deficit and beg voter forgiveness as they deferred action on a whole slew of campaign promises. Would the commitment to end teacher testing meet a similar fate? ${ }^{51}$

The Professional Learning Program was killed in three stages. First, it was dealt a symbolic coup de grace in the Throne Speech of November 20: "New programs to ensure teaching excellence - designed in cooperation with a revitalized Ontario College of Teachers - will replace the expensive and unproductive 'teacher testing' program." The teacher federations were pleased at the inclusion of this statement, but not yet ready to relax. "Please be advised that the Liberal government has indicated, through its Speech from the Throne, that it will be moving forward to reform the Ontario College of Teachers and withdraw the recertification program," ETFO members were told by their president, Emily Noble. "In the meantime, it is important that members continue to boycott Professional Learning Plan (PLP) courses." The telling blow was struck by Gerard Kennedy, the new Liberal Education Minister, in a courteous but firm public letter to Marilyn Laframboise, chair of the Ontario College of Teachers on December 19. "The government has listened to teachers' concerns about the Professional Learning Program," Kennedy stated, "and plans to introduce legislation in the Spring to repeal the Program." This time, the teachers celebrated. "Re-certification Is Dead!" screamed the bold-type heading of the OECTA Faxagenda. As he had promised, Kennedy introduced a bill to implement the cancellation of mandatory teacher 
re-certification on May 13, 2004, and this measure was finally passed by the legislature on December $15 .^{52}$

And what of the other elements of the Ontario Teacher Testing Program? The language proficiency test for teacher applicants trained in a language other than English or French remained in force and evoked no significant controversy. The Ontario Teacher Qualifying Test survived the change of government, for one more year, and the student teachers in the graduating class of 2004 duly wrote their tests on April 3. In the face of firm opposition to its continuation by the Ontario Deans, however, the 2005 test was cancelled and new legislation passed in the spring of 2006 dealt it the final coup de grace. The College of Teachers released a policy paper entitled "New Teacher Induction: Growing Into the Profession" on December 10, 2003 that virtually disappeared from the radar screen a week later, in the wake of Kennedy's announcement that mandatory teacher re-certification was dead. The idea re-surfaced in the fall of 2005, though, as the means by which the Liberal government replaced the OTQT. The province's New Teacher Induction Program (NTIP) for 2005-06 combined school orientation, specialized professional development and formal mentoring in a mandatory program funded by the provincial government but administered by the school boards. The school-level Teacher Performance Appraisal remained in place, though the part dealing with new teachers was grafted onto the NTIP. Teacher testing was gone, but teacher evaluation, through the New Teacher Induction Program and the Teacher Performance Appraisal, remained alive and well. ${ }^{53}$

\section{Epilogue}

In the pitched political battle between the Progressive Conservative government and the three main teacher federations of Ontario, there were casualties. Initially, the tide had run in the government's favour. Despite an unprecedented province-wide walkout of two weeks' duration, the teachers were unable to prevent the passage of Bill 160, which centralized control of education in the provincial capital. Two years later, the PC party was triumphantly re-elected with another majority, in spite of energetic efforts by the teachers to defeat them. Legislation to implement teacher testing in the form of mandatory recertification for experienced instructors, and an entry-to-the-profession exam for novices, was duly passed through the legislature, notwithstanding the vehement opposition voiced by the teacher unions. Passage of this legislation constituted the high-water mark for the Conservatives in their confrontation with the teachers, however. Vigorous political-action strategies by the teacher federations hampered the implementation of the PLP so that it was only partly in place by the next election. While there were many issues in the electoral campaign of 2003, the teachers' strong dislike of the PCs' teacher-testing policy ensured that most of them would campaign vigorously in support of whichever Opposition candidates - Liberal or NDP - had the best chance to win in each riding.

If the PC party's loss of power can be attributed, in part, to their unsuccessful attempt to implement a highly controversial teacher-testing program over the objections of teachers, so too can the loss of stature by the Ontario College of Teachers be con- 
nected to this policy. At first, the OCT acquitted itself well: standing up to Janet Ecker when the Minister unreasonably demanded instant "advice" on how to implement the government's campaign pledge. In addition, the College's report was likely instrumental in moving the government from its initial preference for periodic teacher exams throughout a career to a one-time test to enter the profession, followed by ongoing but mandatory professional development. The OCT received no thanks for this outcome from the teachers, however, and when it became the willing instrument by which the hated PLP was to be implemented, then the teachers' disdain for their own professional governing body became publicly palpable. In the tug-of-war between teacher unions and the College of Teachers for the loyalty of rank-and-file teachers, the unions won, hands-down. In fact, one of the most attractive parts of the Liberals' platform for classroom teachers was their open commitment to reform the College of Teachers.

Another casualty of the teacher-government battle, culminating in the PCs' defeat in 2003, was the confrontational model of educational policy-making, itself. For eight years, minus a few months when the new leader, Ernie Eves, and his Minister of Education, Elizabeth Witmer, sought to mend fences with the key educational interest groups, the Conservatives had made school policy to fit their lean-government ideals and electioneering interests. They made no pretence of consulting widely in order to build a consensus around a compromise program acceptable to all the major stakeholders. This bold and abrasive approach did seem to work for a while, and the PC government changed much in education in its first half dozen years in office. There was a price to be paid, however, both in non-compliance and opposition from interested groups like the teachers and in a gradual decline in public support. The Ontario political culture values moderation as much as progress, and too much confrontation, for too long, drains a ruling party of its popular appeal. Eventually, the policy-community model re-asserts itself, and all but the most important aspects of educational policy are informally delegated to the experts, the administrators and the interests. ${ }^{54}$

This teacher-testing case study provides a rare insight into the politics of education in Ontario. There are a plethora of special interest groups engaged in the policy field of public education: teacher federations, principals' and supervising officers' councils, parents' organizations and trustees' associations. Each has a mandate to lobby the government - and each other - on behalf of their own membership, and they do so with considerable skill and tenacity. On the institutional side, the influence of the premier's office and cabinet secretariat is immense. Nor can one dismiss the collective might of the vast Ministry of Education, headed administratively by the Deputy Minister, and politically by the Minister of Education. Yet quasi-governmental bodies like the College of Teachers - or more at arm's length, the Association of Deans of Education - proved to be a formidable force to be reckoned with, in the teacher-testing example. The twists and turns of policy development with respect to the Ontario Teacher Testing Program bore a direct relationship to the ebb and flow of political influence held by these assorted interest groups and institutional bodies, as they engaged, only partly in public view, in the intricate dance of power.

The story does not end there, however. The mass of ordinary citizens played their part, too. Indirectly and passively, their collective opinions as measured in polling sur- 
veys had an impact on all the elite players. Public opinion mattered because it was seen as a harbinger of how the next election might turn out. This led to the second, more active, way in which ordinary citizens affected the political process. When one party, which supported teacher testing, was voted out of office and replaced by another, which was committed to repealing the policy, the votes of the people mattered. The campaign activities of the political parties counted. A different policy outcome was the ultimate result. Some interest groups and institutional factions made gains; others lost influence. We need look no further than the fate of the teacher-testing policy from 1999 to 2003 to see that both micro- and macro-politics play their part in creating educational policy in Ontario. ${ }^{55}$ Doubtless this pattern applies in other democratic jurisdictions, as well.

\section{Notes}

1 Ontario Progressive Conservative Party. "Blueprint: Mike Harris' Plan to Keep Ontario on the Right Track.” April 19, 1999. http://www.ontariopc.com/feature/bp_online/ 4-3-d.htm/, retrieved on 18/9/2004.

2 The Throne Speech promise was reiterated by the new Liberal Minister of Education in an open letter to the Chair of the Ontario College of Teachers. Gerard Kennedy to Marilyn Laframboise, December 19, 2003.

3 See, for example, the following popular analysis of the PC government's early years: John Ibbitson, Promised Land: Inside the Mike Harris Revolution (Scarborough, Ont.: Prentice Hall Canada, 1997). Ibbitson was a prominent member of the Queen's Park press gallery in Toronto.

4 R.D. Gidney, From Hope to Harris: The Reshaping of Ontario's Schools (Toronto: University of Toronto Press, 1999), 233; 257-64.

5 In describing various aspects of democratic governance in Ontario, reference will be made to the "political system," as developed in its classic form by David Easton. A Framework for Political Analysis (Chicago: University of Chicago Press, 1965). For a model showing its application to Canada, see Larry A. Glassford, Robert J. Clark \& Larry Chud, Challenge of Democracy: Ideals and Realities in Canada (Scarborough, Ont.: Nelson Canada, 1984), 24-25.

6 Gidney, op.cit., argues that most of the educational program implemented by the PC government fell within the parameters of conventional discussion. He cites their confrontational methods and break-neck pace as the most signal factors distinguishing their regime from previous NDP, Liberal and PC governments in Ontario. For a contrary perspective that cites fundamental, ideologically driven differences between the Harris-era policies and those that came before, see Alan Sears, Retooling the Mind Factory: Education in a Lean State (Aurora, Ont.: Garamond Press, 2003), esp. the Introduction, 1-29.

7 A. Paul Pross, Group Politics and Public Policy (Toronto: Oxford University Press, 1992), esp. 118-130.

8 Ontario Progressive Conservative Party, "Blueprint for Ontario," April, 1999, http://www.ontariopc.com/feature/bp_online/4-3; retrieved on 18/9/2004.

9 Art Chamberlain, "Harris plan would test teachers," in Toronto Star, April 20, 1999, 1.

10 Some form of teacher testing had been instituted in 41 of the 50 American States, by this time. See Diana Pullin, "Key Questions in Implementing Teacher Testing and Licensing," in Journal of Law and Education 30, no. 3, (July, 2001): 383-429.

11 Ibid.; "Tory proposal," The Globe and Mail, April 20, 1999, A7. 
12 Chamberlain, Toronto Star, April 20, 1999, 1, and Caroline Mallan "No new money for teacher training," in Toronto Star, April 21, 1999, 1; "College of Teachers Not Consulted on Re-Certification Plan," OCT News Release, April 22, 1999, http://www.oct.ca/en/CollegePublication/news-archive/, retrieved on 12/2/2004.

13 "Teacher testing top priority: Harris," in Canada NewsWire, May 28, 1999, 1, http://proquest.umi.com/pqdweb?, retrieved on 17/9/2004.

14 Robert Sheppard, "The Harris Factor," in Maclean's, May 17, 1999, 18.

15 Daniel Girard, "Harris touts test theory," in Toronto Star, May 29, 1999, 1.

16 Murray Campbell, "Harris cruises to victory," in The Globe and Mail, June 4, 1999, 1.

17 "College Advises Minister on Teacher Testing Program", Canada NewsWire, April 13, 2000.

18 Donna Marie Kennedy, "Premier's Charter Announcement Takes College of Teachers by Surprise", Professionally Speaking, June, 1999, 6.

19 "Teachers on Notice," Windsor Star, September 3, 1999.

20 Don Lajoie, "Liberals slam teacher testing," Windsor Star, September 23, 1999.

21 "No Clear Answers on Many Complex Issues That Surround Teacher Recertification," Professionally Speaking, September 1999, 19-20. Research in the United States had failed to find any predictive validity in the teacher tests currently in use there. See Claudia S. Dybdahl, Donna Gail Shaw, and Dennis Edwards, "Teacher Testing: Reason or Rhetoric," in Journal of Research and Development in Education, 30, no. 4, (Summer 1997): 248-254.

22 Janet Ecker to Donna Marie Kennedy, November 10, 1999, reproduced in Professionally Speaking, March 2000, 28.

23 Donna Marie Kennedy to Janet Ecker, November 26, 1999, reproduced in ibid., 29; Ibid., "The College Remains Committed to Consulting on Teacher Testing," 6.

24 Ibid., "Developing 'Complete, Accurate and Reliable' Advice on Teacher Testing," 14; Kristin Rushowy, "Teacher assessment proposals include everything but actual test," Toronto Star, February 11, 2000.

25 Ontario College of Teachers, Maintaining, Ensuring and Demonstrating Competency in the Teaching Profession, April, 2000.

26 Ibid., "Advice to the Minister of Education," 123-127; "ETFO responds to teacher testing report," Canada NewsWire, April 13, 2000, http://proquest.umi.com/pqdweb?index, retrieved on 11/2/2004.

27 "Government fulfills promise to test teachers," Ministry of Education press release, May 11, 2000, and "Statement to the Legislature by the Honourable Janet Ecker, Minister of Education on the Ontario Teacher Testing Program," May 11, 2000, http://mettowas21.edu.gov.on.ca/eng/document/nr/00.05, retrieved on 28/1/2004.

28 Adrian Humphreys, "Province's teachers to face country's toughest testing," in National Post, May 12, 2000; "Government moving forward with teacher testing program," Canada NewsWire, July 13, 2000, http://proquest.umi.com/pqdweb?index, retrieved on $11 / 2 / 2004$.

29 "Ontario Teacher Testing Program," Ontario Ministry of Education website, last updated August 15, 2000. http://www.edu.gov.on.ca/eng/teacher/testing/testing.html, retrieved on $17 / 8 / 2000$.

30 Wendy Matthews “Update on Teacher Testing," etfo voice 3, no.4, Summer 2001, 8-9; "Government Teacher Testing Plans - Update June 2001," OSSTF Website, http://www.osstf.on.ca/www/issues/tchrtesting/chart.html, retrieved on 3/7/2004; Education Improvement Commission, The Road Ahead - V: A Report on Improving Student Achievement, Toronto, December 2000, 11-13; Memo - Dr. Janet Flewelling to Dean Ian Crawford, "Report on the O.C.T. Meeting Regarding an Entry to the Profession Test," October 13, 2000. 
31 Author's notes from two conference presentations by Paul Anthony of the Ontario Ministry of Education: (1) O.T.F./O.A.D.E. Teacher Education Conference, Toronto, May 5, 2001; (2) Ministry of Education/Faculties of Education Annual Conference, Toronto, June 4, 2001; “Teacher Graduates to be Tested," Ministry of Education News Release, March 14, 2001.

32 "Ontario passes law introducing Canada’s first mandatory teacher testing plan," Canadian Press, June 28, 2001, http://proquest.umi.com/pqdweb?index, retrieved on 4/2/2004; Larry M. Capstick \& J.W. (Joe) Atkinson to "Dear College Member," August 13, 2001; "Helping Teachers Stay Up To Date," in Report to Ontario Taxpayers, Fall 2001, 7-8.

33 "Teacher Testing Won't Help Students Learn, Elementary Teachers Say," Canada News Wire, June 7, 2001, http://proquest.umi.com/pddweb?index, retrieved on 11/2/2004; "Re-certification Announcement Concerns College," OCT News Release, June 7, 2001, http://www.oct.ca/en/CollegePublications/news-archive, retrieved on $12 / 2 / 2004$.

34 Form letter: Larry M. Capstick \& J.W. (Joe) Atkinson to 40,000 College Members in first group, October 15, 2001.

35 Ontario Minister of Education, News Release - "Province sets clear standards for teacher appraisal," Statement by Janet Ecker, Minister of Education - "Introduction of the 'Quality in the Classroom Act, 2001,' and Backgrounder - "Supporting teacher quality and teaching excellence;" all October 15, 2001, http://www.edu.gov.on.ca/eng/teacher/testing/testing.html.

36 Allen Pearson, "Questions raised by teacher testing," in Faculty of Education Newsletter, University of Western Ontario, Winter 2001.

37 "Hands off teacher testing," OSSTF Update 29, no.1, September 11, 2001; "OECTA opposes decertification," Agenda, October 2001; Ontario Ministry of Education booklet, Ontario Teacher Testing Program: An Overview (Queen's Printer for Ontario, 2002).

38 "Defiant teachers to protest testing," Windsor Star, November 14, 2001; "Compulsory tests 'beneficial': Harris," The Canadian Press, n.d.; "Forced upgrade," The Report, January 7, 2002, 39; "The Blue Pages," Professionally Speaking, March, 2002, 35-43; "Errors betray confusion at College of Teachers," OECTA Agenda, January 2002.

39 "The Never-Ending Story: Teacher Re-Certification," Ontario Secondary School Teachers' Federation, November 6, 2001, http://by7fd.bay7.hotmail.msn.com/ cgi-bin/getmsg?, retrieved on 15/2/2004.

40 "Strategies for Success: Recertification," in etfo voice, Summer 2002, 15; Lorrie Goldstein, "College Daze," Toronto Sun, June 7, 2002.

41 Sarah Sacheli, "Teachers threaten boycott," Windsor Star, February 26, 2002; "Windsor Students United Behind OECTA's Political Action, OECTA Faxagenda, February 27, 2002; "Re-Certification," OECTA Agenda, November, 2002.

42 Larry M. Capstick, Chair, and J.W. (Joe) Atkinson, Registrar, to Larry Arthur Glassford, July 4, 2002; "P.L.P Now Involves All Members," Professionally Speaking, September, 2002, 29; Lois Browne, "Gathering Momentum - an evolving P.L.P," Professionally Speaking, September, 2003, 28-30; Ontario College of Teachers, Member's Handbook, 2004, 32-35; "College of Teachers: the good, the bad and the ugly," OSSTF News Release, May 27, 2003, http://by7fd.bay7.hotmail.msn.com/cgi-bin/, retrieved on $15 / 2 / 2004$.

43 Janet Ecker, “Teacher testing promotes excellence," Windsor Star, March 13, 2002; "Minister Highlights More Change for Teaching Profession in 2002," Professionally Speaking, March 2002, 40-41; "Education Minister Announces Accreditation Regulation During College Visit," ibid., March 2003, 55; "OECTA leads a year of re-certification resistance," OECTA Agenda, November 2002, 3.

44 Ontario Deans of Education, "Why teachers were testy," The Globe and Mail, March 11, 2002. 
45 Ontario Principals' Council, “The O.P.C and E.T.S Partnership,” in The Register 3, no. 3, Fall, 2001; "Ontario Teacher Qualifying Test, 2002," Ontario Principals' Council Website, http://opc.inline.net/pacc/print.htm?, retrieved on 23/01/02; "Pilot Teacher Test Welcomed by Ontario's Principals," April 23, 2002, OPC Website, http://www.principalls,on,ca/print.htm, retrieved on 11/21/2004.

46 Michael Manley-Casimir, OADE, \& Larry M. Capstick, OCT, to Hon. Janet Ecker, February 18, 2002; Memorandum from Suzanne Herbert, Deputy Minister of Education, to Deans of Education, February 22, 2002; "Why teachers are testy," Op.Cit.; Renée Rawlins, president OISE/UT Student Teachers' Union to Dear (recipient), March 18, 2002.

47 Caroline Mallan \& Louise Brown, "Teacher test won't count," Toronto Star, April 23, 2002; "Government Heeds College Advice on Teachers Qualifying Test," OCT Website, April 23, 2002, http://www.oct.ca/en/CollegePublications/news-archive, retrieved on 12/2/2004; Ministry of Education News Release, "97 per cent of teacher candidates pass qualifying test: Witmer,” June 3, 2003, MOE Website, http://www.edu.gov.on.ca/ eng/document/nr/03.06, retrieved on 22/01/2004; "Students in Limbo as Teacher's tests lost," in Chatham This Week, June 25, 2003; Ontario Teacher Qualifying Test, Registration Bulletin, 2002/2003.

48 R.D. Gidney, From Hope to Harris: The Reshaping of Ontario's Schools (Toronto: University of Toronto Press, 1999), $216 \& 233$.

49 In Windsor-Essex, for example, the OSSTF and ETFO locals collaborated in the publication of a 24-page glossy black-and-white election booklet, which contained laudatory reviews of the Liberal and NDP platforms and local candidates, and slammed the Conservative record. See Provincial Election 2003 -This time the Tories must Go!, by OSSTF District 9 and ETFO Greater Essex Local, September 2003.

50 Theresa Boyle, "Education is 'top priority': McGuinty," Toronto Star, September 10, 2003; Paddy Moore, "Party Platforms; Education," CBC Website - Ontario Votes 2003, http://www.cbc.ca/ontariovotes2003, retrieved on 10/02/2004; "Provincial Election 2003 - Issues at a Glance,” ETFO Website, http://www/etfo.ca, Updated September 2003; Ernie Eves to "Dear Fellow Ontarian," PC Campaign letter, September 4, 2003.

51 "Landslide," Toronto Star, October 3, 2003; Richard Gwyn, "Ontario voted against change," Toronto Star, October 5, 2003.

52 Ontario Throne Speech, November 20, 2003, forwarded by e-mail; "Elementary teachers are pleased," ETFO Media Release, December 19, 2003, and "Recertification Update, November 2003," Emily Noble, President, to ETFO Members, November 26, 2003, both at http://www.etfo.ca, and both retrieved on 22/07/04; Gerard Kennedy to Marilyn Laframboise, December 19, 2003; "Re-certification is Dead," OECTA Faxagenda, December 19, 2003; "Gerard Kennedy, Minister of Education Statement to the Legislative Assembly," May 13, 2004, Ministry of Education website, http://www.edu.gov.on.ca/eng/document/nr/, retrieved on 22/05/04; "Grits kill teacher testing," Windsor Star, December 16, 2004.

53 Ontario Teacher Qualifying Test Registration Bulletin, 2003/2004; "Mandatory support program needed for Ontario's new teachers," O.C.T. Backgrounder, December 10, 2003, at http:/www.oct.ca/en/CollegePublications/news-archive, retrieved on 2/2/04; Jon Cowans, "The end of P.L.P. - now what about TPA?," O.S.S.T.F. Update 31, no. 8, February 3, 2004; "Affiliates send alternative professional learning program to government," O.S.S.T.F. Update 31, no. 6, December 9, 2003; Ministry of Education News Release, "Legislation Passes to Boost Student Performance," June 1, 2006, Government of Ontario Home Page, http://ogov-newswire-ca/ontario/GPOE/2006/ 06/01/c2711.html, retrieved on 02/06/2006; Ontario Ministry of Education, "New Teacher Induction Program: 2005-06 Program Guideline,” March 3, 2006. 
54 Certainly, the rhetoric of the new Liberal government paid homage to the Robarts-Davis model of widespread consultation and consensus building. Its first (Throne Speech pledged the government to "treat educators with the respect they deserve," and to replace "conflict, cuts, and chaos" with "cooperation, creativity and a genuine commitment to what's best for our children." Throne Speech, November 20, 2003, Op.Cit.).

55 "Macro", or elite, politics refers to traditional aspects that focus on party battles and election campaigns. "Micro" refers to the less obvious, but none the less real, lobbying activities and public relations measures designed to shape policy outcomes and influence public opinion. For a fuller elaboration of the concepts, see: Larry A. Glassford, "Conflict, Power and Influence Through Time: Challenging the Orthodoxy of Social History," in National History: A Canadian Journal of Enquiry and Opinion, 1, no. 4 (Summer 2000): 307-320. 